\title{
Проблемы развития региональной экономики: итоги работы международной конференции в Туве
}

\author{
Валерий О. Ооржак, Галина Ф. Балакина \\ Тувинский институт комплексного освоения природных ресурсов Сибирского отделения РАН, \\ Российская Федерация
}

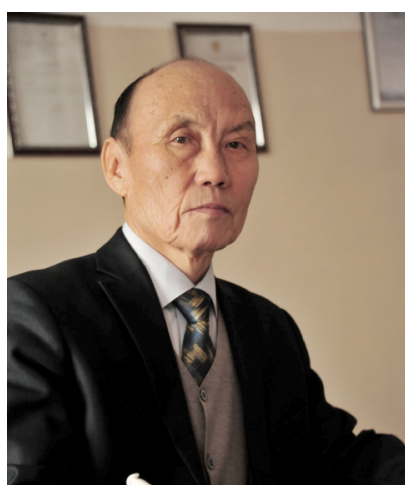

В статье представлен обзор работы 3-й Международной научно-практической конференции «Региональная экономика: технологии, экономика, экология и инфраструктура», которая прошла с 23 по 25 октября 2019 г. в Тувинском институте комплексного освоения природных ресурсов СО РАН (2. Кызыл, Россия). Конференция была посвящена 25-летию образования института и 45-летию первой ячейки академической науки в Туве.

Главной целью конференции было определено изучение и анализ состояния экономики Республики Тыва, регионов Сибири и сопредельных территорий, на базе обсуждения и научного анализа результатов исследований экономических, технологических и экологических процессов в Республике Тыва и сопредельных регионах, выработка предложений по обеспечению динамичного и устойчивого развития территорий в современных условиях.

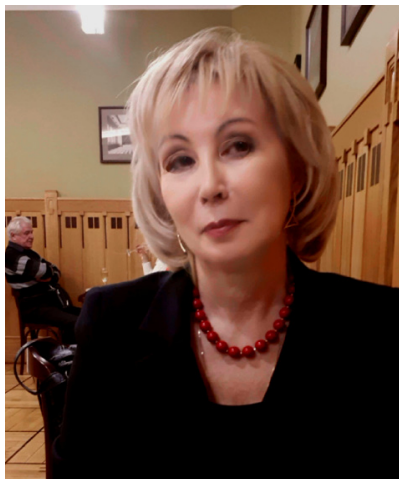

Представленные доклады были рассмотрены на пленарном заседании конференции и пяти секииях. Рассмотрены идеи ряда докладов, в том числе по другим регионам России и мира. Отмечены основные итоги работы конференции, общие рекомендации конференции органам власти Тувы.

Ключевые слова: социально-экономическое развитие; региональная экономика; экология; инновационные технологии; инфраструктурные проблемы; Тува; регионоведение; обзор; ТувИКОПР СО РАН

Ооржак Валерий Окпан-оолович - кандидат экономических наук, заместитель директора, старший научный сотрудник лаборатории региональной экономики Тувинского института комплексного освоения природных ресурсов Сибирского отделения РАН. Адрес: 667007, Россия, г. Кызыл, ул. Интернациональная, д. 117А. Тел.: +7 (394-22) 6-62-18. Эл. aдpec: v.oorgak@yandex.ru ORCID ID: 00000003-2985-0722

Балакина Галина Федоровна- доктор экономических наук, заместитель директора по научной работе Тувинский институт комплексного освоения природных ресурсов Сибирского отделения РАН. Адрес: 667007, Россия, г. Кызыл, ул. Интернациональная, д. 117А. Тел.: +7 (394-22) 6-62-18. Эл. адрес: balakina.gal@yandex.ru ORCID ID: 0000-0003-2387-7190

Oorzhak Valerii Okpan-oolovich, Candidate of Economics, Deputy Director, Senior Research Fellow, Tuvinian Institute for Exploration of the Natural Resources, Siberian Branch, Russian Academy of Sciences. Postal address: 117a Internatsional'naya St., 667007 Kyzyl, Russian Federation. Tel.: +7 (394-22) 6-62-18. E-mail: v.oorgak@yandex.ru

Balakina Galina Fedorovna, Doctor of Economics, Deputy Director for Research, Tuvinian Institute for Exploration of the Natural Resources, Siberian Branch, Russian Academy of Sciences. Postal address: 117a Internatsional'naya St., 667007 Kyzyl, Russian Federation. Tel.: +7 (39422) 6-62-18. E-mail:balakina.gal@yandex.ru 


\title{
Problems of regional economic development: an international conference in Tuva
}

\author{
Valerii O. Oorzhak, Galina F. Balakina \\ Tuvinian Institute for Exploration of the Natural Resource \\ Siberian Branch, Russian Academy of Sciences, Russian Federation
}

\begin{abstract}
The article presents an overview of the 3rd International Scientific and Practical Conference "Regional Economy: Technologies, Economics, Ecology and Infrastructure," which took place from October 23 to 25, 2019 at the Tuvinian Institute of Complex Development of Natural Resources at the Russian Academy of Sciences (Kyzyl, Russia). The conference was dedicated to the 25th anniversary of the institute and the 45th anniversary of the first institution of academic research in Tuva.

The main purpose of the conference was to study and analyze the state of economy of the Republic of Tuva, in the regions of Siberia and neighbouring territories. Through discussions and analysis of the outcomes of research into economic, technological and environmental processes in the Republic of Tuva and neighboring regions, proposals were made on how to ensure dynamic and sustainable development of these territories under current conditions.

The papers accepted for the conference were presented at the plenary session and five panels. Some paper suggestions were also discussed, including those concerning other regions of Russia and the world. The conference concluded by reflecting on its outcomes and formulating policy recommendations for the authorities of Tuva.
\end{abstract}

Keywords: socio-economic development; regional economy; Tuvinian Institute for Exploration of the Natural Resources SB RAS; ecology; innovative technologies; infrastructure problems; Tuva; regional studies; review

Oorzhak V. O. and Balakina G. F. Problems of regional economic development: an international conference in Tuva. The New Research of Tuva. 2020, № 1 [online] Available at: https://nit.tuva.asia/nit/article/view/913 (access date ...). DOI: 10.25178/nit.2020.1.14

Работа III Международной научно-практической конференции «Региональная экономика: технологии, экономика, экология и инфраструктура» осуществлялась 23-25 октября 2019 г. в Тувинском институте комплексного освоения природных ресурсов СО РАН (г. Кызыл, Россия). Конференция приурочена к 25-летию образования вышеназванного института и 45-летию первой ячейки академической науки в Туве. Инициатором проведения научно-практической конференции, как и предыдущих, выступила лаборатория региональной экономики ТувИКОПР СОРАН (Региональная экономика..., 2015: Электр. ресурс; Региональная экономика ..., 2017).

С 1990-х годов в Республике Тыва, одновременно с другими регионами России, происходит сложный, зачастую драматичный, переход к рыночным методам хозяйствования, осуществляется модернизация процессов развития, проводятся социальные преобразования, совершенствуются основы правового регулирования экономики и экологической сферы. Эти процессы определяют особенности социально-экономического, экологического развития региона, изменяют требования к применяемым технологиям добычи и переработки минерального сырья и природных ресурсов. Новые вызовы ставят перед учеными задачу поиска инновационных решений возникающих проблем, поэтому обмен научными взглядами, гипотезами и результатами исследований остается востребованным и необходимым, что обусловливает актуальность темы конференции. 
Цель конференции - исследование состояния экономики Республики Тыва, регионов Сибири и сопредельных территорий на основе научных дискуссий по результатам анализа экономических, технологических, экологических и инфраструктурных вопросов, выработка предложений по обеспечению динамичного и устойчивого развития регионов в современных условиях. Программным комитетом под региональной экономикой понимается система научных направлений по изучению проблем развития территорий, объединяющих исследования как собственно экономики региона, так и его экологии, социологических процессов, проблем поиска и включения в хозяйственный оборот месторождений полезных ископаемых, создания социальной и производственной инфраструктуры интенсификации производства. То есть, понятие региональной экономики здесь трактуется как синтез исследований региональной экономики и управления территориями, региональной социологии, региональной экологии, региональной геологии и региональные аспекты технологических процессов. При этом регион рассматривается как часть государства. К рассмотрению на конференции допускаются результаты изучения и комплексного анализа процессов в регионе как функциональной и структурной подсистемы природного комплекса, экономики и социальной сферы Тувы и сопредельных территорий.

В задачи конференции входили обмен научно-практической информацией коллег в целях изучения и анализа состояния экономики регионов, выявления причин возникновения проблем, определение современных тенденций, в том числе неравномерности уровня развития, и выработка предложений по решению проблем социально-экономического развития с учетом особенностей каждого региона, в том числе таких приграничных и депрессивных территорий как Республика Тува. То есть главным объектом внимания конференции стали регионы, обладающие специфическими признаками: приграничное положение, депрессивность, необходимость вовлечения природных ресурсов в хозяйственный оборот без ухудшения экологической ситуации. Также к задачам относились определение перспектив рационального использования ресурсов на территории Центрально-Азиатского региона, выявление подходов к осуществлению важных проектов по их освоению, формирование комплекса инструментов регулирования, а также оказание методической помощи молодым ученым в планировании и осуществлении научных исследований.

В целях успешной реализации поставленных задач были сформированы авторитетные организационный и программный комитеты - из числа ученых и управленцев-практиков. В состав организационного комитета входили представители академической науки и Правительства Республики Тыва, в том числе Александр Владимирович Брокерт, первый заместитель Председателя Правительства Республики Тыва (председатель), Валерий Ильич Котельников, канд. техн. наук, директор ТувИКОПР СО РАН; гос-жа Баасанжап Ганцецег, генеральный консул Монголии в г. Кызыле РФ (сопредседатели), Валерий Окпан-оолович Ооржак, канд. экон. наук, заместитель директора ТувИКОПР СО РАН (заместитель председателя), а также члены оргкомитета: Давид Федорович Дабиев, канд. экон. наук, заведующий лабораторией региональной экономики ТувИКОПР СО РАН, Сергей Григорьевич Прудников, канд. геол.-мин. наук, заведующий лабораторией «Геодинамики, магматизма и рудоообразования» ТувИКОПР СО РАН; Шончалай Чудурукпаевна Соян, канд. экон. наук, ведуший научный сотрудник ТувИКОПР СОРАН; Херел Буян-оолович Бадарчи, канд. экон. наук, старший научныЙ сотрудник ТувИКОПР СО РАН.

Программный комитет возглавляла Галина Федоровна Балакина, д. э. н., заместитель директора ТувИКОПР СО РАН по научной работе. Члены программного комитета: Тана Михайловна Ойдуп, канд. социол. наук, ученый секретарь ТувИКОПР СО РАН; Валентин Викторович Заика, докт. биол. наук, заведующий лабораторией «Биоэкология» ТувИКОПР СО РАН; Александр Иванович Жданок, докт. физ.-мат. наук, гл. науч. сотр. ТувИКОПР СО РАН, Борис Комбуй-оолович Кара-Сал, докт. техн. наук, заведующий лабораторией материаловедения ТувИКОПР СО РАН.

Пленарное заседание 23 октября 2019 г. открыл Валерий Ильич Котельников, директор ТувИКОПР СО РАН; с приветствиями выступили: Елена Владимировна Каратаева, министр экономики Республики Тыва; г-н Мянганбаяр Ганбат, консул Монголии в г. Кызыле РФ, Чойган Николаевна Самбыла, докт. биол. наук, директор Тувинского научного центра; Светлана Суруновна Курбатская, докт. геогр. наук, сотрудник Тувинского научного центра; Урана Владимировна Ондар, канд. химич. наук, проректор Тувинского государственного университета по научной работе. Кандемир Канчырович Ооржак, научный сотрудник Тувинского института гуманитарных и прикладных социально-экономических исследований при Правительстве Республики Тыва огласил приветствие директора института - канд. экон. н. Буяна Алексеевича Донгака. 


\section{НОВЫЕ ИССЛЕДОВАНИЯ ТУВЫ}

www.nit.tuva.asia

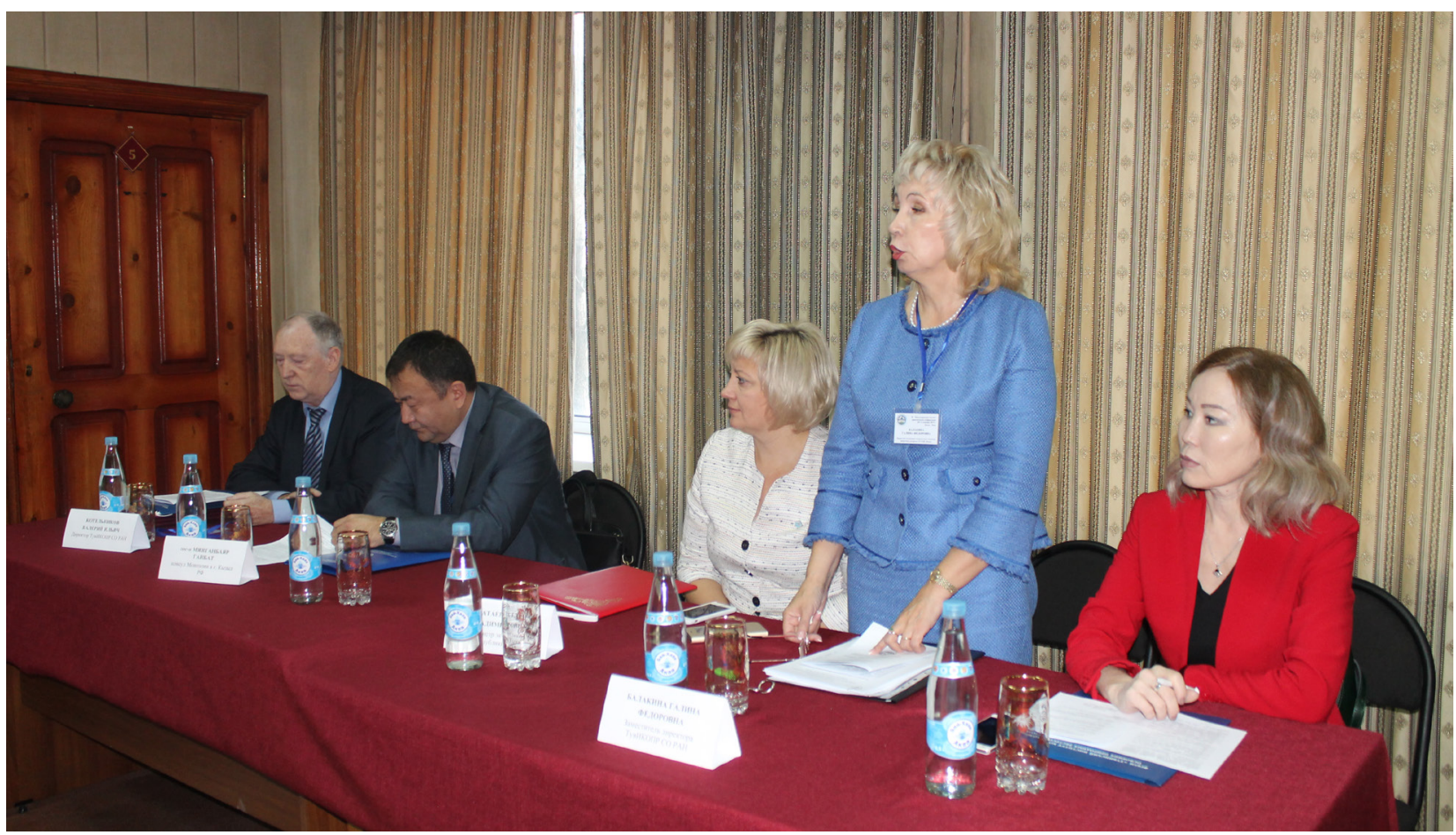

Фото 1. Президиум пленарного заседания. Фото Ю. Ю. Самбыла. Photo 1. At the plenary session of the conference. Photo by Yu. Yu. Sambyla.

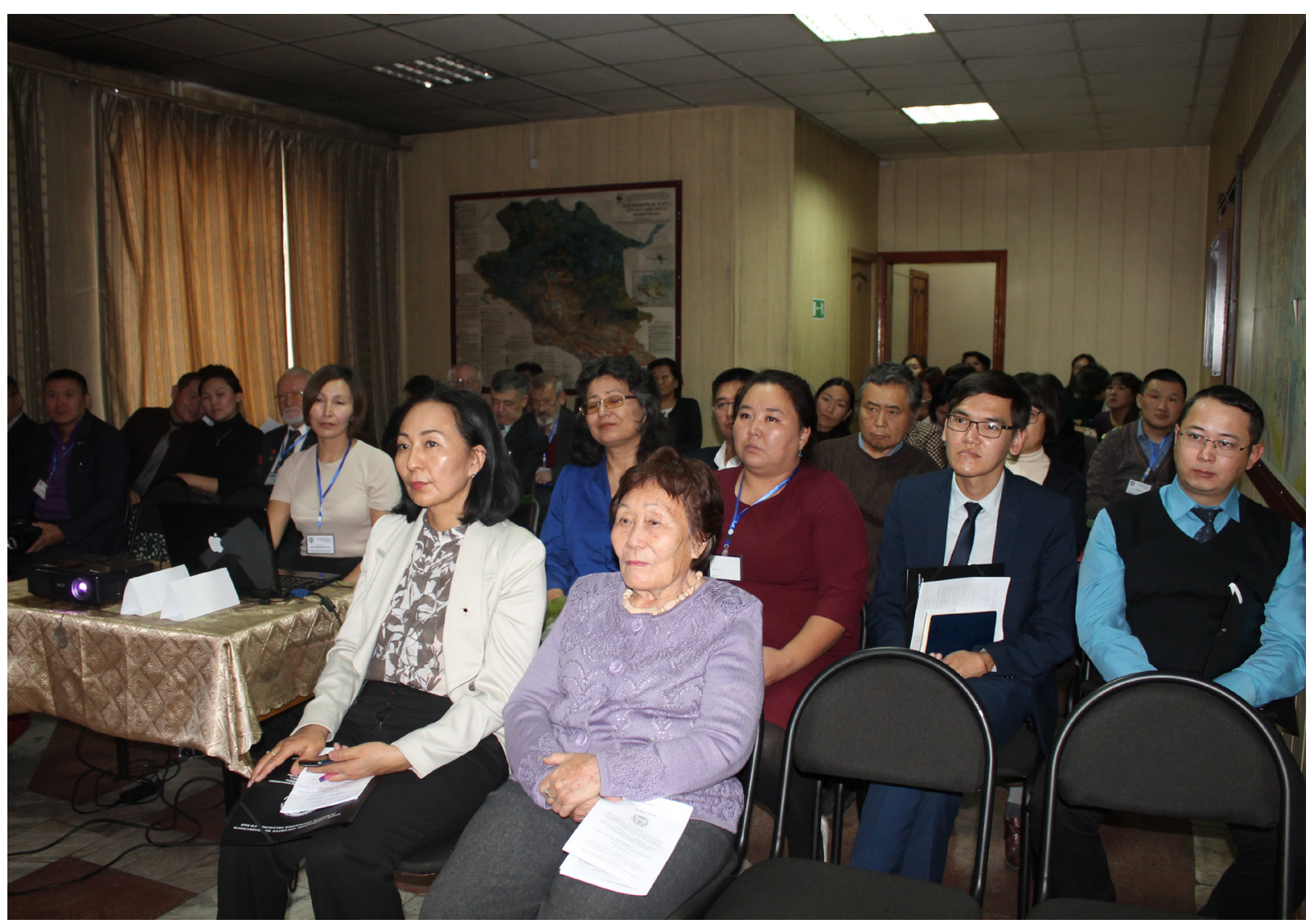

Фото 2. Участники конферениии. Фото Ю. Ю. Самбыла. Photo 2. Conference participants. Photo by Yu. Yu. Sambyla. 
В. И. Котельников подчеркнул актуальность и значимость проводимой конференции для Республики Тыва и сопредельных территорий, их социально-экономического развития как одного из важнейших инструментов реализации результатов научных исследований, проводимых в различных научных учреждениях, в том числе в таких институтах Российской академии наук, как ТувИКОПР СО РАН.

Е. В. Каратаева отметила, что сегодняшняя международная конференция, как и предыдущие, занимает ключевое место среди научных мероприятий года в Туве. Министр подчеркнула, что многие предложения и рекомендации первых двух конференций института, разработанные на основе результатов научных исследований ученых, были уже учтены и приняты при формировании программ и стратегий развития отраслей экономики и социальной сферы региона, при создании новых инфраструктурных проектов и крупных предприятий, в том числе по освоению природных ресурсов и минерального сырья.

«В 2015 году мы с вами на первой конференции обсуждали подписанное Дмитрием Анатольевичем Медведевым распоряжение Российской Федерации от 17 апреля 2015 года № 678-р, которым утверждён План мероприятий, направленный на социально-экономическое развитие республики на 2015-2025 годы, это важнейший документ развития региональной экономики», - сказала она. К настоящему времени выполнен ряд предусмотренных мероприятий, в том числе проведена реконструкция аэропортового комплекса г. Кызыла. Он готов к приему и отправке современных воздушных судов, уже эксплуатируется высококачественная искусственная взлетно-посадочная полоса, современное светосигнальное оборудование. Принято распоряжение Правительства РФ от 28 августа 2019 г. № 1902-р об открытии международного аэропорта «Кызыл». 2 июля 2019 г. в г. Улан-Батор между авиакомпанией «Тува Авиа» и авиакомпанией «HunnuAir» подписано соглашение о намерениях по осуществлению регулярных перелетов по перевозке пассажиров по маршрутам Улан-Батор - Улангом - Кызыл и Кызыл - Улангом - Улан-Батор. В дальнейшем будут организованы прямые рейсы: Улан-Батор Кызыл и Кызыл - Улан-Батор. Реализация проекта строительства железнодорожной линии Элегест Кызыл - Курагино вошла в активную стадию: работы начнутся в 2020 году.

В настоящее время, по словам Е. В. Каратаевой, ведется разработка проектно-сметной документации по реконструкции автомобильного пункта пропуска через государственную границу Российской Федерации «Хандагайты». В 2020-2021 гг. будет проведена реконструкция и пункт начнет работать в многостороннем режиме. В рамках заседания Совета Межрегиональной Ассоциации экономического взаимодействия субъектов Российской Федерации «Сибирское Соглашение» 28 июня 2019 г. в г. Кызыле был подписан Протокол о намерениях сотрудничества о возможности разработки проекта по созданию трансграничного автомобильного коридора «Красноярск (Красноярский край, Россия) Абакан (Республика Хакасия, Россия) - Кызыл (Республика Тыва, Россия) - Хандагайты (Республика Тыва, Россия) - Улангом (Увсанурский аймак, Монголия) - Ховд (Кобдоский аймак, Монголия) - Урумчи (Синьцзян-Уйгурский автономный район Китайской Народной Республики)».

На конференции было заслушано 67 устных докладов, включая 3 пленарных. Общее количество докладов, включая заочные, составило 133, которые были представлены 144 участниками из 65 организаций (14 иностранных организаций и 51 российская). Из регионов России приняли участие 51 ученый. По сравнению с первыми двумя конференциями (Ооржак, Балакина, 2016; 228; Соян, Балакина, 2018;176-177), количество участников, а также учреждений и организаций, которые они представляют, увеличилось более чем в два раза. Это свидетельствует о возрастающей значимости данного научного мероприятия.

В ходе проведения конференции были обозначены и уточнены актуальные тенденции изменения экономических, технологических, экологических, инфраструктурных и природопользовательских процессов социально-экономического развития современного приграничного региона и других территорий, определены пути привлечения внимания ученых к исследованию данной проблематики, содействия активному научному творчеству и профессиональному становлению молодых исследователей, выработаны рекомендации по практическому осуществлению теоретических предложений.

Зарубежное участие в конференциях, проходящих в Туве, традиционно осложняется транспортной труднодоступностью региона. Поэтому участники из других стран преимущественно представили доклады в заочной форме, прислав тексты докладов. Доклады рассмотрены как изучение опыта параллельных региональных исследований. В статьях коллеги сосредоточили свое внимание на экологических, геополитических и социально-экономических проблемах развития производительных сил в регионах, а также рассматривали вопросы совершенствования технологий, химической кинетики и химической инженерии. 
Например, в работе А. В. Егориной, Г. М. Салыкбаевой, К. А. Артемьевой «Этногеографическая ситуация приграничных территорий Казахстана и России» из Восточно-Казахстанского государственного университета им. С. Аманжолова (Усть-Каменогорск, Казахстан) представлены результаты анализа статистического и картографического материала, на основании которого сформулированы основные особенности этногеографической ситуации приграничных территорий Казахстана и России. Определён состав этносов приграничья с наибольшим суммарным удельным весом в структуре населения соседствующих стран.

Сотрудник вышеназванного университета Р. С. Бейсембаева в докладе «Влияние зоны приграничной торговли на развитие транспортно-логистической инфраструктуры Восточно-Казахстанской области» обосновывает возможность создания в приграничных зонах Казахстана и России ряда международных центров приграничного сотрудничества. Приоритетом дальнейшего развития транспортной инфраструктуры Восточно-Казахстанской области (особенно при планировании новых маршрутов), по мнению автора, должно быть вхождение в транспортную структуру формирующегося регионального коммуникационного коридора и формирование узлового торгово-логистического центра.

Профессор В. Н. Василенко (Донецкий национальный технический университет, г. Донецк) в докладе «Системный подход к экономической диагностике развития регионов» рассматривает развитие региона через призму основных его парадигм: территории, экономической системы и экономического пространства, что создает условия для более точного выбора объектной базы для применения экономической диагностики развития регионов. Это позволяет определить основные процессы, способные нарушить системный характер организации воспроизводства ресурсов.

В докладе С. Г. Ше (г. Ансан, Республика Корея) «Геоэкономический подход к организации промышленного комплекса в СЭЗ Туманган» приведены результаты геоэкономического анализа экономики Республики Корея; систематизированы внешние факторы снижения южнокорейского экспорта. Автором представлен подход к решению проблемы индустриального комплекса Кэсон: проблемы и достижения социально-экономического проекта. Подчеркивается, что «роль Кэсонского индустриального комплекса в аспекте межкорейского сотрудничества сегодня трудно переоценить». Комплекс был основан по соглашению с правительством Южной Кореи в 2004 г. на территории Северной Кореи. В состав технопарка вошло более 120 южнокорейских предприятий малого и среднего бизнеса, суммарный выпуск которых с 2004 г. по 2015 г. составил 3 млрд. 376,55 млн дол. Следует отметить также, что в этой промышленной зоне было занято более 50 тыс. северо- и южнокорейских граждан. Докладчиком сформулированы цель и задачи организации нового транспортного коридора через СЭЗ «Туманган» в Европу по Северному морскому пути.

В работах зарубежных участников конференции по рациональному природопользованию значительной внимание уделяется необходимости системного анализа природных процессов, включая применение современных ГИС-технологий. Так, в докладе Н. К. Кабдрахмановой, М. Н. Мусабаевой (Евразийский национальный университет им. Л. Н. Гумилева, г. Нур-Султан, Республика Казахстан) «Структурный анализ ландшафтов бассейна верхней части реки Иртыш» подчеркивается, что исследования структурно-функциональных связей геосистем в бассейне реки должны опираться на принцип сквозной системности. «Как единая геосистема, бассейн реки - это сверхсложная, экзорегулируемая, импульсивно динамическая геосистема, ограниченная двумя особыми типами поверхностей: пороговыми - вертикальными (например, гляциальной зоной) и контактными - горизонтальными (пойма реки)». Поэтому при изучении геосистем внутреннего стока помимо литогенной основы целесообразно рассматривать такие дифференцирующие факторы, как поверхностный сток, компоненты макро- и микросубстратных этажей геосистем, к которым относятся параметры водного и теплового баланса, продуктивность и урожайность фитомассы.

Доклад Э. И. Чембарисова, М. Н. Рахимовой, С. Р. Шодиева, Г. Т. Ахмеджановой, 3. У. Тиллаевой (Научно-исследовательский институт ирригации и водных проблем, Навоийский педагогический институт, Ташкентский институт инженеров ирригации и механизации сельского хозяйства, г. Ташкент, Узбекистан) «ГИС-технологии в современных экологических исследованиях бассейна Аральского моря» посвящен изложению результатов анализа гидроэкологической безопасности и мониторинга бассейна Аральского моря. В ходе изучения были созданы: комплекс электронных водохозяйственных и гидроэкологических карт бассейна, базы данных, содержащих атрибутивную информацию о гидрологическом и гидроэкологическом состоянии водных ресурсов, а также средства расчета и отображения комплексных показателей качества воды на основе разнородных пространственно рас- 
пределенных данных. На созданной в ходе работы карте экологического мониторинга бассейна Аральского моря были представлены гидрохимические данные в виде диаграмм или таблиц за 2000-2014 гг. Результаты исследований с использованием ГИС-технологий позволяют более реально оценить гидроэкологическую ситуацию, раскрыть принципиальные особенности методики мониторинга аридной зоны, что может стать основой прогнозирования экологической обстановки в водохозяйственном комплексе Аральского бассейна водоохранными и водохозяйственными организациями.

Итоги исследования проблемы разработки и совершенствования технологий переработки природных ресурсов на основе инноваций также были представлены в докладах иностранных участников конференции. В докладе Г. С. Яблонского (Вашингтонский университет в Сент Луисе, США) была предложена совместная кинетика (jointkinetics) как новая парадигма для химической кинетики и химической инженерии, основная идея которой заключается в проведении серии кинетических экспериментов со специальными информационными композициями, сопровождающихся анализом полученной информации. В рамках разработанной теории были представлены новые базовые понятия, т. е. новые инварианты, термодинамические и нетермодинамические; карты событий; возмущенные равновесия (консервативно возмущенное равновесие и обменное равновесие). Совместная кинетика может рассматриваться, по предложению автора, как эффективный инструмент для выявления детального механизма и определения кинетических коэффициентов.

Е. В. Карачевская (Белорусская государственная сельскохозяйственная академия, г. Горки, Республика Беларусь) в работе «Инновационные технологии как фактор развития рынка лекарственного растительного сырья Республики Беларусь» обосновывает необходимость модернизации рынка лекарственного растительного сырья для повышения эффективности его развития. В докладе систематизируются факторы, препятствующие стабильному росту инновационной активности. К ним отнесены: снижение производства отечественной продукции; неразработанность политики государства; высокая стоимость новой техники и технологий; неблагоприятная инвестиционная ситуация в отрасли. Исследователь определяет следующие задачи: обеспечить рост инвестиционной привлекательности отрасли лекарственного растениеводства для частных инвесторов, повысить темпы роста технико-технологического переоснащения организаций рынка лекарственного растительного сырья; разработать и внедрить технологии на инновационной основе.

Пленарные доклады конференции были посвящены проблемам развития экономики Тувы.

Г.Ф. Балакина в докладе «Возможности и перспективы инновационного развития экономики региона») подчеркнула, что особенностью современного этапа развития России и регионов является модернизационный переход от экспортно-сырьевой к инновационной модели роста экономики, который призван повысить качество социально-экономического развития и уровень жизни населения страны. На примере Тувы названы факторы, препятствующие эффективному внедрению инноваций и переходу к экономике знаний. Тем не менее в Республике Тыва имеются возможности для интенсификации инновационных процессов. К факторам, способствующим развитию инновационной сферы отнесены: формирование конкурентоспособных инновационных кластеров (инновационнопромышленного, энергетического, агроэкологического), создание новых высокотехнологичных рабочих мест, рост квалификации работников, динамичное увеличение численности научных кадров, совершенствование системы научных учреждений. Сделан вывод о целесообразности формирования региональной инфраструктуры содействия инновациям, создание системы стимулирования и отбора инновационных инициатив населения, что необходимо осуществлять в рамках реализации стратегии инновационного развития региона.

В пленарном докладе Б. К. Кара-Сала «Возможные направления использования вскрышных пород угледобычи Тувы для производства строительных материалов» выявлены виды, химико-минералогические составы и структурные особенности, а также физико-механические свойства вскрышных пород угледобычи Тувы. Приведены основные направления использования вскрышных пород из отвалов, создавшихся в результате функционирования добывающих предприятий в Туве, для производства строительных материалов в зависимости от их технологичности и химической активности. Докладчик обосновал возможность получения стеновых и теплоизоляционных материалов, а также смешанного вяжущего на основе вскрышных пород углеобогащения, что является перспективным направлением использования попутных продуктов топливоперерабатывающей промышленности. Реализация предложенных разработок может обеспечить значительный экономический и экологический эффект при производстве местных строительных материалов. 
НОВЫЕ ИССЛЕДОВАНИЯ ТУВЫ

www.nit.tuva.asia
№1

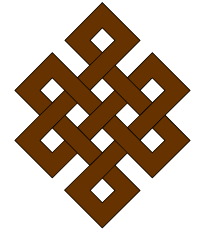

\section{THE NEW RESEARCH OF TUVA}

2020
Novye issledovaniia Tuvy

В пленарном докладе Л.Х. Тас-оол «Состояние воздушной атмосферы г. Кызыла в период 2007-2017 гг.» представлена динамика техногенного загрязнения атмосферы г. Кызыла за последние десять лет. Основные загрязнители города - теплоэнергетические установки, в которых в качестве топлива используются каа-хемские угли марок Г, ГЖ с высоким выходом летучих (до 40\%). В 2017 г. в г. Кызыл и пгт. Каа-Хем общий объем сожженного в печах угля превысил уровень 2007 г. на 31 млн т. В наихудшем состоянии находится центральная зона города. Повысились загрязнения снегового покрова в северной и южной зонах. В целях решения актуальной для столицы республики проблемы загрязнения воздушной атмосферы дымовыми выбросами углесжигания мэрия г. Кызыла предложила проработать вопрос по выпуску брикетов «бездымного» топлива. Также Правительство Республики Тыва в январе 2019 г. одобрило «дорожную карту» по развитию многоэтажной комплексной застройки территории с необходимыми инженерными коммуникациями, в том числе централизацией теплоснабжения, что приведет к снижению загрязнения.

Проблематика исследований в области региональной экономики: технологии, экономики, экологии и инфраструктуры охватывала пять основных направлений, представленных докладами на секциях конференции.

На секции «Социально-экономическое развитие региона: проблемы и перспективы» (руководитель секции Г. Ф.Балакина) было заслушано 13 докладов по актуальным вопросам развития и совершенствования параметров современных процессов экономической динамики и социальной сферы. Наибольший интерес вызвали доклады А. Д. Бегзи «Основные факторы, этапы и особенности урбанизации в Туве» и А. П. Темир-оол «Анализ инвестиционных проектов Республики Тыва в рамках комплексной инвестиционной программы «Енисейская Сибирь».

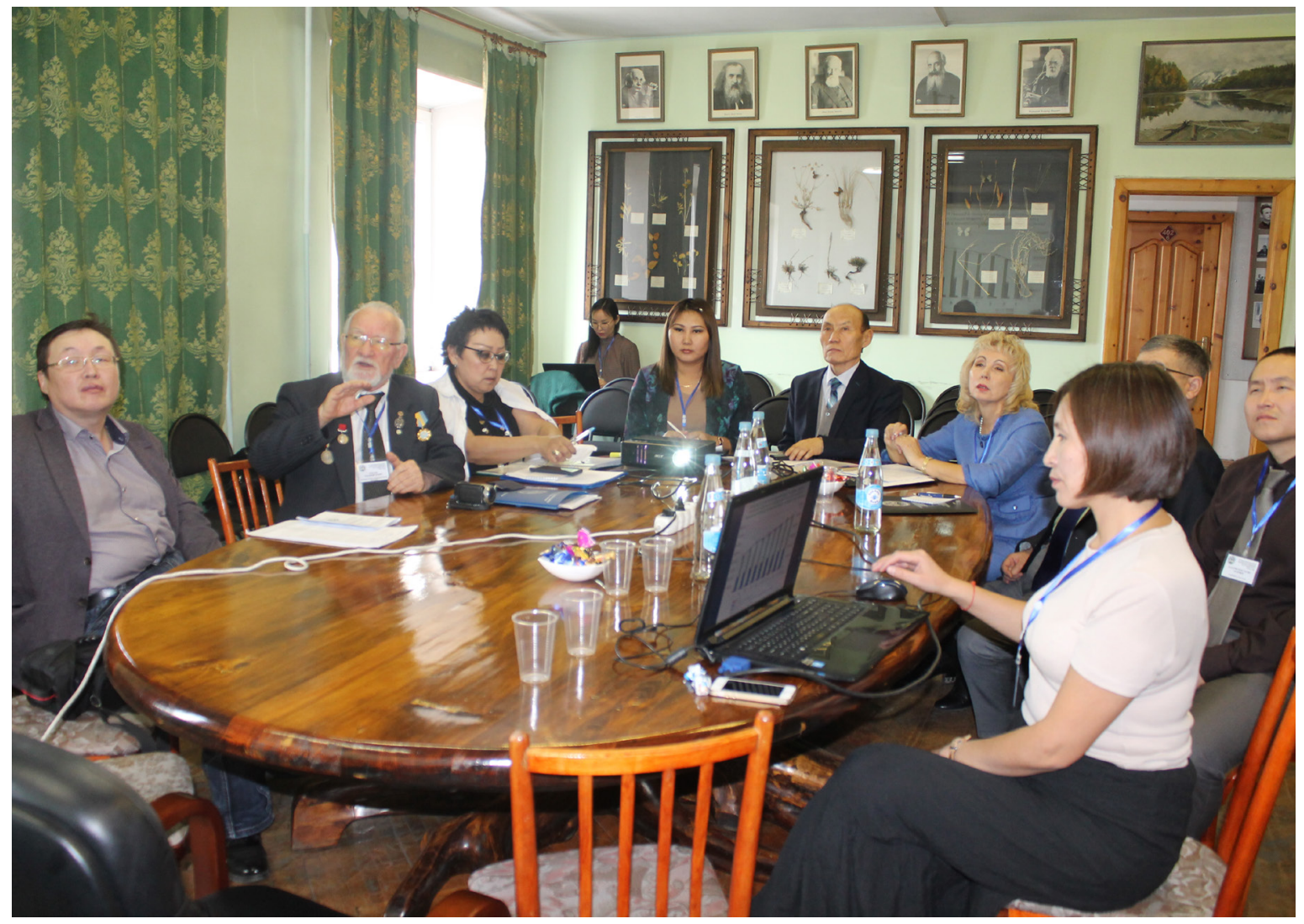

Фото 3. Заседание секции «Социально-экономическое развитие региона: проблемы и перспективы». Фото Ю. Ю. Самбыла.

Photo 3. At the "Socioeconomic development of a region: issues and prospects" session. Photo by Yu.Yu. Sambyla.

На секции «Геология, минерально-сырьевой потенциал и сейсмическая активность Тувы и сопредельных территорий» (руководитель секции - канд. геол.-мин. наук А. М. Сугоракова) было заслушано 14 докладов. Интерес участников вызвали сообщения о динамике состояния водных ресурсов 
(О.И.Кальная, С.Г.Прудников, О.Д.Аюнова «Геологические условия и оценка эколого-гидрохимического состояния водотоков в районе Алгиякского золотоносного узла»); об оценке цикличности сейсмической активности Республики Тыва (С. С. Монгуш «Оценка цикличности сейсмической активности Республики Тыва»). Также заинтересовали доклады о результатах исследования кобальтовых месторождений республики докт. г.-м. н. В. И. Лебедева. Лучшим докладом был признан доклад о проблемах исследования остатков океанического дна в районе пустыни Гоби в Монголии с возрастом 430 млн лет (А. К. Хертек, А. М. Козловский, О. Цэрэнцэгмид, Б. Сухбат «Геохимические и Nd-изотопные характеристики силурийских надсубдукционных офиолитов Юга Заалтайской Гоби, Монголия»).

В ходе работы секции «Математическое моделирование и геоинформационное картографирование природных и антропогенных процессов» (руководитель секции - д. ф.-м. н. А. И. Жданок) было заслушано 8 докладов, тематика которых в значительной степени отражает актуальность применения новых методов анализа: математического моделирования и геоинформационного картографирования - для получения обоснованных научных результатов, выработки рекомендаций по развитию экономики и социальной сферы. В этой связи были интересны доклады А. И. Жданка и А. К. Хурума «Некоторые результаты математического моделирования загрязнения экосферы г. Кызыла дымом ТЭЦ на примере ртути», Х. Б. Куулар «Оценка разнообразия лесов хр. Уюкский по данным Landsat» и Т. М. Ойдуп, Б. С. Монгуш, С. А. Чупиковой «ГИС-анализ инвестиционной привлекательности территорий муниципальных образований Республики Тыва». Значительный интерес вызвал доклад А. Ф. Чульдума, А. Д. Мылдык «Сравнительный анализ спектров горлового пения методами вейвлет и Фурье преобразований».

На секции «Рациональное природопользование и охрана окружающей среды» (руководитель секции докт. биол. наук А. Д. Самбуу и канд. биол. н. Т. П. Арчимаева) было заслушано 32 доклада. Тематика секции отличалась большим разнообразием, в программу были включены доклады, посвященные итогам мониторинга на угледобывающих предприятиях, геохимии вод, почв, структуре ландшафтов как Тувы, так и других территорий России, и даже международному опыту рационального природопользования и охраны окружающей среды. Большая часть представленных докладов были посвящены изучению аржаанов (минеральных источников) Тувы: их гидрохимическим свойствам, а также видовому составу микробных сообществ, развивающихся в их водах. Выявлена прямая зависимость видового разнообразия и обилия в микробных сообществах от температуры вод. Все доклады вызвали живой интерес аудитории, в результате активного обсуждения слушатели выяснили что развитие в минеральных источниках обильных обрастаний зеленого цвета, т.н. микробных матов не является следствием загрязнения источника, но зависит от минерального состава и температуры воды.

Работу секции «Инновационные технологии как фактор развития современного общества» модерировал профессор, докт. техн. н. Б. К. Кара-сал. Всего было заслушано пять докладов. Велись активные обсуждения проблем переработки каменного угля и направлений использования. Наиболее интересным и важным назван доклад Г. Р. Монгуша «Изменение выхода углеродного остатка пиролиза каменных углей, в условиях затрудненного удаления летучих веществ», в котором были отражены результаты исследований неполного сгорания угля, что приводит к образованию большого количества выбросов, ухудшающих экологическое состояние атмосферы г. Кызыла. Для решения данной проблемы предложена комплексная предварительная термическая обработка угля, в результате которой можно получить бездымное топливо, каменноугольную смолу и газ как альтернативный тепловой источник энергии. В докладе М. О. Молдурушку «Технология извлечения мышьяка из отвалов комбината “Тувакобальт”» изложены основные характеристики технологии, разработанной для решения проблемы ликвидации отвалов бывшего комбината Тувакобальт, предложено рассматривать их в качестве техногенного сырья для извлечения металлов, были проведены исследования возможности вывода мышьяка по средствам сульфидирующего обжига и комплексной технологии. По разработанной комплексной схеме получены продукты: кек выщелачивания, диоксид кремния и сульфид мышьяка, которые могут быть использованы как вторичное сырье для получения металлов, строительных материалов, в качестве биоцида для покрытий корпусов морских судов. По комплексной технологии получен патент РФ. Также вызвал значительный интерес доклад Н. Н. Янчат «Сравнительный анализ содержаний элементов-примесей, определенных количественным и полуколичественным анализами в угольном пласте Улуг Каа-Хемского месторождения», по итогам обсуждения научных результатов исследований которого были высказаны рекомендации по продолжению исследований в данном направлении. 
Анализ представленных материалов показал, что наибольшее число докладов посвящено изучению проблем социально-экономического развития регионов, в том числе приграничных, со слаборазвитой экономикой и инфраструктурой (дотационных) - 27 сообщений (35,5\%). Значительную долю составляют материалы, посвященные проблемам рационального природопользования и охране окружающей среды, экологии и природопользования, сохранения особо охраняемых объектов этих территории 24 сообщений (31,6\%). Результаты исследований, посвященных проблемам геологии и минеральносырьевого потенциала Тувы и сопредельных территорий, изучения и сохранения животных и растений, особо охраняемым природным территориям сопредельных регионов представлены в 11 докладах $(14,5 \%)$. Часть докладов - 14 (18,4\%) имеют общетеоретическое значение. Такая структура докладов отражает актуальность и востребованность органами управления итогов разработки и научного обоснования методов и инструментов решения экологических и социально-экономических проблем развития Тувы и сопредельных регионов.

Конференция была организована по инициативе лаборатории региональной экономики института. Аналогичные конференции проводятся в институте с 2009 г. В этом году участники конференции приняли рекомендации проводить такие конференции один раз в два года.

По итогам конференции принята резолюция, содержащая соответствующие научно-теоретические и практические рекомендации, адресованные деятелям науки, Правительству Республики Тыва, министерству экономики Республики Тыва, учреждениям науки и образования, органам власти и средствам массовой информации Тувы. В рекомендациях центральной идеей проходит мысль о мобилизации и координации сил научной общественности для дальнейшего развития научных исследований актуальных вопросов развития экономики Республики Тыва, Центрально-Азиатского региона, законодательно-правовых, инфраструктурных, технологических и экологических проблем трансграничного сотрудничества; проблем геологии и металлогении, генезиса месторождений полезных ископаемых, их промышленного освоения, переработки сырья и отходов производств; актуальных проблем изучения и сохранения биологического разнообразия водных и наземных экосистем, растительного и почвенного покрова, а также математического моделирования, геоинформационного сопровождения изучаемых явлений и процессов, позволяющих оценивать и прогнозировать их динамику. Признано актуальным изучение возможностей дальнейшего развития инфраструктуры Тувы, совершенствования транспортного сообщения с трансграничными регионами Западной Монголии и Северо-Западного Китая, включая строительство железной дороги в регион. Определено, что особенностью современного развития науки в республике является востребованность научного сопровождения проектов Индивидуальной программы социально-экономического развития Республики Тыва, комплексной инвестиционной программы «Енисейская Сибирь», более тесного взаимодействия с региональными органами исполнительной власти. В области совершенствования регулирования инновационного развития региона участники заседания предложили рассмотреть возможность разработки Стратегии инновационного развития Республики Тыва до 2035-2040 гг.; возобновить практику составления ежегодных докладов по развитию инноваций в республике, а также организовать в 2021 г. проведение Тувинского экономического форума, приурочив его к 100-летию образования Тувинской Народной Республики.

Предложено продолжить мониторинговые исследования по проблемам загрязнения озер Тувы и влиянию данного загрязнения на зоопланктон озер; продолжить взаимное сотрудничество сотрудников ТувИКОПР СО РАН и с организациями, осуществляющими экологический мониторинг.

Правительству Республики Тува, Министерству экономики Тувы, рекомендовано создать условия для реализации крупных инвестиционных проектов по добыче полезных ископаемых, создания инновационных промышленных производств, в сельском хозяйстве, туризме; продолжить поддержку традиционного хозяйства коренного населения Тувы на промышленной основе для увеличения продукции традиционных производств в экспорте; создать рабочую группу по решению проблемы переработки мышьяксодержащих отходов комбината «Тувакобальт» с привлечением ученых Сибири; рассмотреть возможность разработки Стратегии инновационного развития Республики Тыва до 20352040 гг.; возобновить практику составления ежегодных докладов по развитию инноваций в республике.

Необходимо заметить, что реализация ряда предложений предыдущих конференций отражены в перспективных программах развития республики: национальный проект «Экология», республиканская целевая программа по утилизации отходов и др., базовых проектах исследований ТувИКОПР СО РАН. 


\section{THE NEW RESEARCH OF TUVA}

В целом, международная научно-практическая конференция продемонстрировала высокий научный уровень докладов и сообщений и собрала представительный состав ученых. Правомерно сделать вывод, что конференция выполнила поставленные задачи, обозначив очередной этап в исследованиях, посвященных проблемам региональной экономики.

Результаты работы конференции нашли отражение в опубликованном сборнике научных материалов (см.: Региональная экономика ..., 2019: Электр. ресурс).

\section{СПИСОК ЛИТЕРАТУРЫ}

Региональная экономика: технологии, экономика, экология и инфраструктура: материалы международной научно-практической конференции, посвящённой 20-летию ТувИКОПР СО РАН (14-15.10.2015 г., Кызыл, Россия) (2015) / отв. ред. Г. Ф. Балакина. Кызыл: ТувИКОПР СО РАН. 328 с.

Региональная экономика: технологии, экономика, экология и инфраструктура Материалы 2-й Международной научно-практической конференции (18-20 октября 2017 г. Кызыл, Россия) (2017) / отв. ред. Г. Ф. Балакина. Кызыл : ТувИКОПР СО РАН. 388 с.

Соян, Ш. Ч., Балакина, Г. Ф. (2018) II Международная научно-практическая конференция «Региональная экономика: технологии, экономика, экология и инфраструктура» (г. Кызыл, 18-20 октября 2017 г.) [Электронный ресурс] // Новые исследования Тувы. № 1. C.174-184. DOI: 10.25178/nit.2018.1.15

Региональная экономика: технологии, экономика, экология и инфраструктура: материалы 3-й международной научно-практической конференции, посвящённой 25-летию ТувИКОПР СО РАН и 45-летию академической науки в Туве (23-25.10.2019 г., Кызыл, Россия) (2019) / отв. редактор В. О. Ооржак. Кызыл : ТувИКОПР СО РАН. 520 с.

Ооржак, В. О., Балакина, Г. Ф. (2016) Международная научно-практическая конференция «Региональная экономика: технологии, экономика, экология и инфраструктура» (г. Кызыл, 14-15 октября 2015 г.) [Электронный ресурс] // Новые исследования Тувы. № 2. C. 224-230.URL: https://nit.tuva.asia/ nit/article/view/104 (дата обращения: 10.12.2019).

\section{REFERENCES}

Regional'naia ekonomika: tekhnologii, ekonomika, ekologiia i infrastruktura [Regional Economy: Technologies, Economics, Ecology and Infrastructure] (2015) / Materials of the International Scientific and Practical Conference Dedicated to the 20th Anniversary of TuvIKOPR of the Russian Academy of Sciences (14-15.10.2015, Kyzyl, Russia). Ed. by G. F. Balakina. Kyzyl, TuvIKOPR SO RAN. 328 p. (In Russ.).

Regional'naya ekonomika: tekhnologii, ekonomika, ekologiya i infrastruktura [Regional Economy: Technology, Economics, Ecology and Infrastructure] (2017) / Materials of the 2nd International Scientific and Practical Conference (October 18-20, 2017, Kyzyl, Russia). Ed. by G. F. Balakina. Kyzyl, TuvIKOPR SO RAN. 388 p. (In Russ.).

Soyan, Sh. Ch. and Balakina, G. F. (2018) II Mezhdunarodnaya nauchno-prakticheskaya konferentsia «Regional'naya ekonomika: tekhnologii, ekonomika, ekologia i infrastruktura» (Kyzyl, 18-20 oktyabrya 2017 g.) [II International Scientific and Practical Conference "Regional Economy: Technologies, Economics, Ecology and Infrastructure" (Kyzyl, October 18-20, 2017)]. The New Research of Tuva, no. 1, pp. 174-184. (In Russ.). DOI: 10.25178/nit.2018.1.15

Regional'naya ekonomika: tekhnologii, ekonomika, ekologiya i infrastruktura [Regional Economy: Technologies, Economics, Ecology and Infrastructure] (2019): Materials of the 3rd International Scientific and Practical Conference Dedicated to the 25th Anniversary of TuvIKOPR of the Russian Academy of Sciences and the 45th Anniversary of Academic Science in Tuva (23-25.10.2019, Kyzyl, Russia). Ed. by V. O. Oorzhak. Kyzyl, TuvIKOPR SO RAN. 520 p. (In Russ.).

Oorzhak, V. O. and Balakina, G. F. (2016) Mezhdunarodnaya nauchno-prakticheskaya konferenciya «Regional'naya ekonomika: tekhnologii, ekonomika, ekologiya i infrastruktura» (Kyzyl, 14-15 oktyabrya 2015 g.) [International Scientific and Practical Conference "Regional Economics: Technologies, Economics, Ecology and Infrastructure” (Kyzyl, October 14-15, 2015)]. The New Research of Tuva, no. 2, pp. 224-230. URL: https:// nit.tuva.asia/nit/article/view/104 (access date: 10.12.2019).

Submission date: 15.12.2019. 